\title{
Conditions of the Quality of Life and Life Satisfaction of Mothers of Preterm Babies in Poland
}

\section{Mariola Bidzan ${ }^{1 *}$ and Łucja Bieleninik ${ }^{2}$}

${ }^{1}$ Institute of Psychology, University of Gdańsk, Gdańsk, Poland

${ }^{2}$ GAMUT, Uni Health, Uni Research, Bergen, Norway

\section{Premature Birth Trauma}

According to the World Health Organization, the correct duration of pregnancy in women is 38 to 42 weeks. Pregnancy terminated with delivery between the $22^{\text {nd }}$ and $37^{\text {th }}$ week is called the premature birth, and the born infant is called a preterm baby. Currently premature birth is the most frequent complication occurring in case of unifetal $[1,2]$ and multifetal [3-7] pregnancies. The indicator of premature births in Poland decreases year by year, nevertheless it is still higher than in other developed European countries and it is estimated as approx. $8 \%$ [8].

Premature birth is a distressing situation for women. Therefore, can premature birth be considered as a psychological trauma? Many scientists think that premature birth is indeed a psychological trauma due to the emotional background and intensity of affects [914], as well as its short-term and long-term consequences. It may condition, especially in case of a difficult and complicated delivery, the Posttraumatic Stress Disorder, PTSD [15]. Data presented in literature, which refer to the occurrence of PTSD symptoms after the delivery, are not unequivocal. It is estimated that at least between $9 \%$ [16] to $34 \%$ [17] of women in labor experienced giving birth as a trauma. It is worth emphasizing that birth can be a traumatic event before it actually occurs (the perspective of giving birth, including life threatening premature birth). It is underlined that help provided to parents in case of a premature birth trauma is a crisis intervention and is analogical to the one provided to people suffering from PTSD [10]. Factors, which determine the perception of a premature birth as a traumatic event, include the following: parents' anxiety whether the child will survive; diametrically changeable infant's situation and chronic uncertainty about the situation; loss of the 'fantasy baby'; anxiety about the infant's further somatic health; availability of negative information about the long-term consequences of premature birth and a mother's confrontation with her traumatic experience from her childhood [9].

Preterm babies form a heterogenic clinical group, whose health state is conditioned by their maturity, birth mass and fetal age; nevertheless, due to the immature life functions body systems they require special supervision and care [18]. It is estimated that $80 \%$ of deaths during the postpartum period are related to premature birth [19]. Currently, infants born in the $24^{\text {th }}$ week of pregnancy have $50 \%$ chances for surviving, in the $25^{\text {th }}$ week $-70 \%$, in the $26^{\text {th }}$ week $-80 \%$. It is assessed that $1 / 3$ of infants born between the $23^{\text {rd }}-25^{\text {th }}$ week of fetal age, $40 \%$ of those born between the $26^{\text {th }}-29^{\text {th }}$ week and $65 \%$ of those born between the $30^{\text {th }}-33^{\text {rd }}$ week of fetal age will not have any health problems. Others are diagnose to suffer from various diseases [20]. The most important ones are presented in Table 1 .

Can this fact have an impact on the assessment of the quality of life and life satisfaction of these babies' mothers? If so, is a baby's state of health the only factor affecting this assessment, or are there any other conditions of the quality of life and life satisfaction or preterm babies' mothers? If so, what are they?

\section{'Becoming' a Preterm Baby's Parent}

In addition, premature birth trauma has to be considered in terms of adopting a new parental role, i.e. 'being a preterm baby's parent', which the spouses/partners have not been prepared to during the pregnancy. The premature birth problem is closely related to the problem of infants' survival rate indicator, and potential complications. Due to the medical progress infants weighing less than $1000 \mathrm{~g}$, being just 28 weeks old, are nowadays rescued [4,19]. Also introducing surfactants in treatment of respiratory failure increased the survival rate among infants born before the $29^{\text {th }}$ week of pregnancy and weighing between 500 and $750 \mathrm{~g}$ three times [8]. It is worth adding that the minimum age for a preterm baby's survival is the $23^{\text {rd }}$ week of gestation [21] Therefore in recent years the main problem has been not keeping preterm babies alive, but diminishing the consequences of premature birth, so that preterm babies do not differ from children born on due date. In our study we verified factors affecting the quality of life and life satisfaction of preterm babies' mothers. We adopted Allen's model (Figure 1), which considers a birth to be a traumatic event.

Our study included 109 patients from the Obstetrics Clinic at the Medical University in Gdańsk, who gave birth to 137 preterm babies: 86 from unifetal pregnancies and 51 from multifetal pregnancies, 80 girls (58.4\%), 57 boys (41.6\%). The impact of the following variables was assessed: Pregnancy termination date; Birth weight; Apgar scale result; Pregnancy type: correct versus threatened; Birth type: physiological birth versus $\mathrm{C}$-section; Baby position at birth: head down, breech,

\begin{tabular}{|l|c|c|c|}
\hline & $23^{\text {rd }}$ and $25^{\text {th }}$ & $26^{\text {th }}$ and $29^{\text {th }}$ & $30^{\text {th }}$ and $33^{\text {rd }}$ \\
\hline Respiratory Distress Syndrome (RDS) & Almost all & Most & $25 \%$ \\
\hline Chronic Lung Disease (CLD) & $65 \%$ & $50 \%$ & $10-15 \%$ \\
\hline Patent Ductis Arteriosus (PDA) & $40-50 \%$ & $40-50 \%$ & $40-50 \%$ \\
\hline $\begin{array}{l}\text { Periventricalar/Intraventrical } \\
\text { Haemorrhage (PVH/IVH) I }\end{array}$ & $15-20 \%$ & $5-10 \%$ & \\
\hline $\begin{array}{l}\text { Periventricular leukomalacia (PIV) } \\
\text { Retinopathy of prematurity (ROP) }\end{array}$ & $100 \%$ & $75 \%$ & \\
\hline Infections & $50 \%$ & $30 \%$ & $15 \%$ \\
\hline Necrotizing enterocolitis (NEC) & $5-10 \%$ & $5-10 \%$ & \\
\hline
\end{tabular}

Source: Own work, based on Linden [21]

Table 1: The most frequent health problems with preterm babies depending on their fetal age.

*Corresponding author: Prof. Mariola Bidzan, Institute of Psychology, University of Gdańsk, 4, Bażyńskiego str. 80-952 Gdańsk, Poland, Tel:+48 6023161 61; E-mail: mariola.bidzan@ug.edu.pl

Received March 26, 2013; Accepted March 26, 2013; Published April 30, 2013

Citation: Bidzan M, Bieleninik $Ł$ (2013) Conditions of the Quality of Life and Life Satisfaction of Mothers of Preterm Babies in Poland. J Socialomics 2: e117. doi:10.4172/2167-0358.1000e117

Copyright: @ 2013 Bidzan M, et al. This is an open-access article distributed unde the terms of the Creative Commons Attribution License, which permits unrestricted use, distribution, and reproduction in any medium, provided the original author and source are credited. 


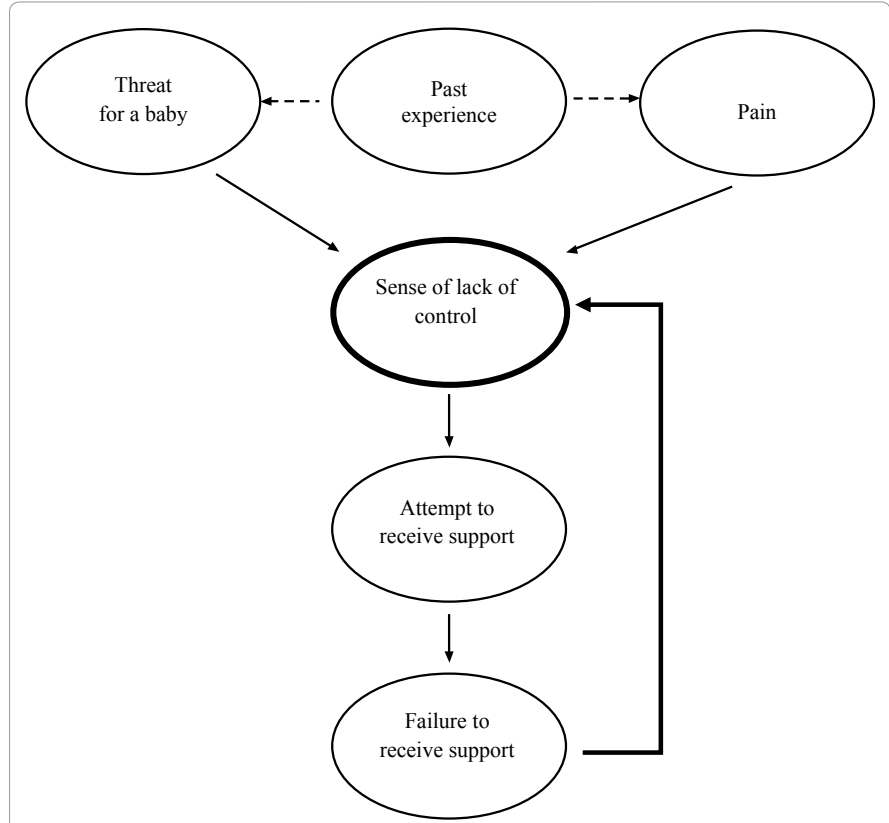

Figure 1: Factor facilitating the transformation of birth into a traumatic experience. Source: Allen (1998).

shoulder presentation; History of negative procreation experience; Subjective impact of a women on the course of delivery; Similarity of the own baby to the fantasy one (in terms of appearance and behavior); Psychomotor development of a baby; Quality of the marital relation; Social support (including: the expected support, received support and the assessment of the quality of the received support).

The obtained results indicate that the assessed quality of life and life satisfaction of preterm babies' mothers is affected by the birth date (preterm versus on time), birth type (physiological versus C-section), subjective impact of a woman on the course of delivery, similarity of the own baby to the fantasy one (in terms of appearance and behavior), psychomotor development of a baby, quality of the marital relation, support received from the medical personnel and the partner. Currently it cannot be stated unequivocally that these factors play identical role with all preterm babies' mothers, nevertheless biological factors (biomedical predicators, e.g. birth date, birth type), psychological factors (e.g. impact of a women on the course of delivery) and social ones (especially the quality of the marital relation and social support) affect the assessed quality of life and life satisfaction of preterm babies' mothers.

Due to the fact that giving birth to a preterm baby affects the functioning of the whole family, the conditions of the assessed quality of life and life satisfaction of mothers (and fathers) require further investigation. The results may trigger the implementation of interdisciplinary actions aimed at not only stimulating the development of disordered areas with preterm babies, but also improving the physical, psychological and social state of parents affected by the preterm birth trauma.

\section{References}

1. Raba G, Marszał J (1998) Preterm delivery-economic nature of the problem? Practical Gynaecology 1: 28.

2. Czajkowski K (2009) Diagnosis of preterm delivery. Perinatology. Neonatology the Ginekologia 2: 165-168.

3. Wilczyński J, Nowakowska D, Jaczewski B, Wenerski J, Oszukowski P, et al (2000) The risk of preterm birth in twin pregnancy. Gynecology Poland 11: 1487-1495.

4. Helwich $E$ (2002) The causes of preterm birth and other risk factors resulting from prematurity. Helwich E. (ed.): Wcześniak.Warszawa: PZWL 11-20.

5. Pawelczyk L, Derwich K (2003) Multiple pregnancy after assisted reproductive technologies. In: Bręborowicz GH, Malinowski W, Ronin-Walknowska E (eds) multiple pregnancy. OWN, Poznan 50-56.

6. Malinowski W (2009) The epidemic of multiple pregnancies. A new problem in obstetrics. Perinatology, Neonatology and Gynecology 2: 90-93.

7. Oleszczuk J, Sawulicka-Oleszczuk H (2009) Prematurity as a medical problem, family and social. In: Pilewska-Kozak, AB (ed.) Care prematurely. PZWL, Warsaw 17-24.

8. Bieleninik $七$ (2012) Children born prematurely in the perception of mothers Wide. Harmonia Universalis, Gdansk.

9. Kmita G (2004) Early intervention psychological violence against children born prematurely and their families in an intensive care neonatal and infan pathology. Exercise Section of Clinical Child Psychology, Polish Psychological Association 45-64.

10. Piekarska A (2005) Prematurity-hospital trauma characteristics, effects and prevention. Auckland University of Technology New Zealand 11: 95-107.

11. Sochocka L, Pirogowicz I (2006) Quality of life in preterm infants - the role of medical personnel and family. Family Medicine \& Care Review 2: 490-493.

12. Łuczak-Wawrzyniak J. (2009) Mother premature-psychological and socia situation during the child's stay in the hospital and after you leave the neonatal unit. Ginekologia Praktyczna 1: 7-8.

13. Bidzan M, Bieleninik $Ł$, Zdolska A, Salwach D (2009) Bond with a child in the prenatal period in case of prematurely born children. In: Turowski K (ed.) Wellness and success, NeuroCentrum, Lublin 3: 35-54.

14. Bieleninik $Ł$, Preis J, Bidzan M (2010) Determinants of emotional bond with the child during the prenatal period in multiple pregnancies and single. Perinatology, Neonatology the Ginekologia 3: 223-231.

15. Bielawska-Batorowicz E, Siddiqui A (2008) A study of prenatal attachment with Swedish and Polish expectant mothers. Journal of Reproductive and Infant Psychology 26: 373-384.

16. Gamble J, Creedy D (2009) A counselling model for postpartum women after distressing birth, experiences. Midwifery 25: 21-30.

17. Soet JE., Brack GA., Dilorio C (2003) Prevalence and Predictors of Women 's Experience of Psychological Trauma During Childbirth. Birth 1: 36-46.

18. Kostuch M (2009) The infant was born prematurely - distinct anatomical and physiological. In: Pilewska-Kozak, AB (ed.) Care prematurely, PZWL, Warsaw 44-60.

19. Szczepański M, Kamianowska M, Grabowska M (2009) Prediction of a premature newborn. In: Pilewska-Kozak, AB (ed.) Care prematurely, PZWL, Warsaw 223-234.

20. Szczepański M, Kamianowska M, Grabowska M (2009) Minimizing the care and treatment prematurely born infant. In: Pilewska Kozak, AB (ed.) Care prematurely, PZWL, Warsaw, 176-186.

21. Wechsler Linden D, Trenti Paroli E, Wechsler Doron M (2007) Premature, The first six years of life. Medical Publishing, Warsaw 545-546. 